ISSN 0258-7122

Bangladesh J. Agril. Res. 39(4): 685-692, December 2014

\title{
FEASIBILITY OF INTERCROPPING LEAFY VEGETABLES AND LEGUMES WITH BRINJAL
}

\author{
M. R. ISLAM ${ }^{1}$, M. T. RAHMAN ${ }^{2}$, M. F. $\operatorname{HOSSAIN}^{3}$ AND N. ARA ${ }^{3}$
}

\begin{abstract}
An experiment was conducted during 2010 and 2011 to find out the suitable crop combination for increasing total productivity, return and maximize land utilization through intercropping system. Six treatments viz. Brinjal 100\% + Red amaranth $100 \%$, Brinjal 100\% + Leaf amaranth 100\%, Brinjal 100\% + Jute as patshak 100\%, Brinjal 100\% + Mungbean 60\%, Brinjal 100\% + Blackgram 60\% and sole of base crops (brinjal) were used in the study. Results showed that different intercropping combination did not influenced yield and yield contributing characters of brinjal. The yield of brinjal comparatively lower in intercropping but total productivity increased due to additional yield of leafy vegetables and legumes. The increases in total productivity in terms of brinjal equivalent yield (BEY) was 8.80 to $26.67 \mathrm{t} / \mathrm{ha}$ in intercrop combination compared to base crop. All the intercropping combinations were higher in terms of brinjal equivalent yield, gross return and benefit cost ratio (BCR) over sole crops. Among the intercropping combinations, Brinjal 100\% $(100 \mathrm{~cm} \times 75 \mathrm{~cm})$ + Mungbean $60 \%$ (three rows mungbean in between brinjal rows maintained 30 $\mathrm{cm}$ apart rows with continuous seeding) was the most feasible and profitable intercropping system in respect of brinjal equivalent yield (20.85 t/ha), gross return (Tk.312750/ha), gross margin (Tk.212693/ha) and benefit cost ratio (3.13).
\end{abstract}

Keywords: Intercropping, leafy vegetables, legumes, brinjal.

\section{Introduction}

Brinjal (Solanum melongena L.) as a vegetable crop is cultivated round the year throughout the country. It is a long durated (240-280 days) and wide spaced (100 $\mathrm{cm} \times 75 \mathrm{~cm})$ crop. So, there is a great scope to cultivate short durated (30-40 days) leafy vegetable and legumes (65-75 days) in the inter row space of brinjal. Leafy vegetable like red amaranth, leaf amaranth, jute and legumes viz., mungbean and blackgram being short structure quick growing crops can be easily intercropped between two rows of brinjal at early growth stage. The practice of intercropping of leafy vegetable and legumes with brinjal is provided high yield and income. In the contrary, legumes crop can be added additional nitrogen in the

\footnotetext{
${ }^{1}$ Senior Scientific Officer, Agronomy Division, Regional Agricultural Research Station, Bangladesh Agricultural Research Institute (BARI), Ishurdi, Pabna, ${ }^{2}$ Senior Scientific Officer, Agronomy Division, ORC, BARI, Gazipur, ${ }^{3}$ Senior Scientific Officer, Horticulture Research Center, RARS, Ishurdi, Pabna, ${ }^{4}$ Principle Scientific Officer, Horticulture Research Center, BARI, Gazipur, Bangladesh.
} 
soil and it improved the soil fertility. Mian (2008) reported that mungbean supply $56.20,60.62$ and $66.93 \mathrm{~kg} \mathrm{~N}$ under low, moderate and high nutrient level, respectively. In Bangladesh small farmers constitute $79.4 \%$ of our farming community and their cultivated lands are shrinking day by day (MOA, 2014). In those context, intercropping is one of the viable technology to ensure efficient utilization of their resources for increased production and family income. Intercropping offers the possibility of yield advantage relative to sole cropping through yield stability and improved yield in tropical and sub tropical areas (Nazir et al., 2002; Malik et al., 2002; Bhatti et al., 2005). Besides, multiple cropping may ensure proper utilization of resources towards increased production per unit area and time on a sustainable basis (Ahmad et al., 2007). However, very few studies have been conducted in the past about vegetables/legumes intercropping system. Considering the above facts, this trial was undertaken to find out the suitable crop combination for increasing total productivity, return and maximize land utilization.

\section{Materials and Method}

The experiment was conducted during 2010 and 2011 at the farm of Regional Agricultural Research Station (RARS), Ishurdi, Pabna. The soil of experimental site was clay loam in texture having $\mathrm{P}^{\mathrm{H}} 7.26$, organic matter $1.05 \%$, total nitrogen $0.059 \%$, available phosphorus $11 \mu \mathrm{g} / \mathrm{ml}$, available potassium $0.12 \mathrm{meq} / 100 \mathrm{~g}$ soil, sulphur $13 \mu \mathrm{g} / \mathrm{ml}$, boron $0.20 \mu \mathrm{g} / \mathrm{ml}$ and zinc $1.8 \mu \mathrm{g} / \mathrm{ml}$. Six treatments viz., $\mathrm{T}_{1}=$ Brinjal $100 \%+$ Red amaranth $100 \%, \mathrm{~T}_{2}=$ Brinjal $100 \%$ + Leaf amaranth $100 \%$, $\mathrm{T}_{3}=$ Brinjal $100 \%+$ Jute $100 \%, \mathrm{~T}_{4}=$ Brinjal $100 \%+$ Mungbean $60 \%, \mathrm{~T}_{5}=$ Brinjal $100 \%+$ Blackgram $60 \%$ and $\mathrm{T}_{6}=$ Sole crop of brinjal were evaluated. The trial was set up in a randomized complete block design (RCBD) with three replications. The sole crop of brinjal and intercropped treatments were fertilized with cowdung $10 \mathrm{t} / \mathrm{ha}$ and 140-50-100-15-2-0.5 kg/ha N-P-K-S-Zn-B in the form of urea, triple super phosphate, muriat of potash, gypsum, zinc sulphate and boric acid, respectively. One third of $\mathrm{N}$, half of $\mathrm{K}$ and full amount of cowdung, P, S, B, $\mathrm{Zn}$ were applied during final land preparation. Remaining $\mathrm{N}$ and $\mathrm{K}$ were applied in three equal installments at 20, 40 and 60 days after transplants (DAT) as ring method around the brinjal plant. Brinjal (Var. BARI Brinjal-8) as base crop and red amaranth (var. BARI Red Amaranth -1), leaf amaranth (var. BARI Leaf Amaranth -2), Jute (Binapatshak-1), mungbean (var. BARI Mungbean-6) and blackgram (var. BARI Blackgram -3) were used as intercrops in this study. The unit plot size was $4 \mathrm{~m} \times 3 \mathrm{~m}$. The sole crop of brinjal was planted at a spacing of $100 \mathrm{~cm} \times 75 \mathrm{~cm}$. In intercropping system three rows of mungbean $(60 \%)$ and blackgram $(60 \%)$ were intercropped in between brinjal rows @ $40 \mathrm{~kg}$ seed/ha maintaining $30 \mathrm{~cm}$ apart rows with continuous seeding. After 20 days after sowing (DAS) mungbean and blackgram plants were thinned out keeping $6-7 \mathrm{~cm}$ plant to plant distance. Red amaranth, leaf amaranth and jute seed were broadcast 
(100\%) in between brinjal rows at the rate of 2, 1.5 and $15 \mathrm{~kg}$ seed/ha. Brinjal (thirty days old seedling), seed of red amaranth, leaf amaranth (danta shak), jute (patshak), mungbean and blackgram were planted/sown on 20 and 25 March 2010 and 2011, respectively. Harvesting of brinjal was started on 20-25 July and continuous to 24-27 November in 2010 and 2011, respectively. Red amaranth, leaf amaranth and jute (patshak) were harvested on 15, 21; 21, 25 and 27, 30 April 2010 and 2011, respectively. Blackgram was harvested on 21 and 25 May, 2010 and 2011, respectively. Two pickings of mungbean were done at 60-65 and 70-75 DAS, respectively in both the years. After pickings, the mungbean plants were incorporated (5.36 ton biomass/ha) in soil. Three irrigations were done in the experimental field. First was applied at just after transplanting (brinjal) and sowing (component crop) of the crop. Second and third irrigation were applied at 80 and 160 days after transplanting (DAT) of brinjal. Weeding was done as per requirement. Spinosad (Tracer $45 \mathrm{SC}$ ) at the rate of $0.4 \mathrm{ml} /$ litre water was sprayed on brinjal for control of brinjal shoot and fruit borer at active vegetative, fruit setting and fruit developing stage. Data on yield and yield contributing characters were taken and analyzed statistically. Data on yield and yield attributes of brinjal for two consecutive years showed similar trend. So, these data were pooled and means were adjudged by Least Significant Difference (LSD) test at 5\% level of significance. Brinjal equivalent yield (BEY) was converted by converting yield of intercrops on the basis of presenting market price of individual crop following the formula:

$\mathrm{BEY}=$ Yield of intercrop Brinjal $+\frac{\mathrm{Yi} \times \mathrm{Pi}}{\text { Price of brinjal }}$ Where, $\mathrm{Yi}=$ yield of intercrops (leafy vegetables/legumes) and $\mathrm{Pi}=$ Price of intercrop (leafy vegetables/legumes). Land equivalent ratio (LER) values were determined from the yield data of the crops according to Mian (2008).

$\mathrm{LER}=\mathrm{RY}_{\mathrm{b}}+\mathrm{RY}_{\mathrm{i}}=\frac{\mathrm{B}_{\mathrm{IY}}}{\mathrm{B}_{\mathrm{SY}}}+\frac{\mathrm{B}_{\mathrm{EYCC}}}{\mathrm{B}_{\mathrm{SY}}}$

Where,

$\mathrm{RY}_{\mathrm{b}}=$ Relative yield of brinjal (main crop)

$\mathrm{RY}_{\mathrm{i}}=$ Relative yield of intercrops (vegetables and legumes)

$\mathrm{B}_{\mathrm{IY}}=$ Intercrop yield of brinjal

$\mathrm{B}_{\mathrm{SY}}=$ Sole crop yield of brinjal

$\mathrm{B}_{\mathrm{EYCC}}=$ Brinjal equivalent yield of component crops $\{$ (component crop yield in intercrop $\times$ price of component crop)/price of brinjal $\}$. 
Benefit cost analysis was also done. The total mean rainfall 974.72, 38.59, 50.54, 191.79 and $179.86 \mathrm{~mm}$ was recorded in brinjal, red amaranth/leaf amaranth, jute, mungbean and blackgram, respectively during the growing season (Table 4). The distribution of rainfall was higher in 2011 than 2010 and the crop as well as yield performance was also comparatively better in 2011 than 2010. It indicates that rainfall had positive effect on crop growth and development.

\section{Results and Discussion}

\section{Yield and yield contributing characters of brinjal}

There was no significant difference in yield and yield attributes of brinjal due to intercropping of leafy vegetables/legumes i.e. growing of intercrops in interspaces between brinjal rows did not affect the base crop (Table 1). The number of fruit/plant ranged from 21.26 to $23.33 \mathrm{~cm}$ where maximum number of fruit/plant was obtained in sole brinjal (23.33). The lower number of fruit/plant was recorded in Brinjal 100\% + Jute 100\% intercropping combination. Similar trend was found in case fruit length.

Table1. Number of fruit/plant, fruit length and fruit yield/ha of brinjal in brinjal- leafy vegetables-legumes intercropping system (pooled data of 2010 and 2011).

\begin{tabular}{c|c|c|c|c}
\hline Treatments & $\begin{array}{c}\text { Number of } \\
\text { fruit/plant }\end{array}$ & $\begin{array}{c}\text { Fruit length } \\
(\mathrm{cm})\end{array}$ & $\begin{array}{c}\text { Fruit yield/plant } \\
(\mathrm{kg})\end{array}$ & $\begin{array}{c}\text { Fruit yield } \\
(\mathrm{t} / \mathrm{ha})\end{array}$ \\
\hline $\mathrm{T}_{1}$ & 21.79 & 15.81 & 1.20 & 15.03 \\
$\mathrm{~T}_{2}$ & 22.20 & 16.16 & 1.11 & 15.11 \\
$\mathrm{~T}_{3}$ & 21.26 & 16.22 & 1.10 & 15.01 \\
$\mathrm{~T}_{4}$ & 22.87 & 16.65 & 1.10 & 16.33 \\
$\mathrm{~T}_{5}$ & 22.59 & 16.47 & 1.14 & 16.19 \\
$\mathrm{~T}_{6}$ & 23.33 & 16.61 & 1.12 & 16.46 \\
\hline $\mathrm{LSD}_{(0.05)}$ & $\mathrm{NS}$ & $\mathrm{NS}$ & $\mathrm{NS}$ & $\mathrm{NS}$ \\
$\mathrm{CV}(\%)$ & 6.36 & 3.94 & 7.52 & 7.19 \\
\hline
\end{tabular}

$\mathrm{NS}=$ Not significant

The maximum fruit yield (16.46 t/ha) was obtained from brinjal sole crop but statistically identical to intercropped combinations. Among the intercropped combinations the maximum brinjal yield was recorded when it was intercropped with mungbean (16.33 t/ha) and blackgram (16.19 t/ha). After harvest of mungbean the plants were incorporated with the soil that's may add additional organic matter $(\mathrm{OM})$, nitrogen and other nutrients elements resulting higher fruit yield of brinjal. On the other hand, brinjal $100 \%$ + red amaranth $100 \%$, brinjal 
$100 \%$ + leaf amaranth $100 \%$ and brinjal $100 \%$ + jute $100 \%$ intercropped combination, the fixed amount of applied fertilizer were uptake both the base (brinjal) and component (leafy vegetables/legumes) crops. Additional nutrients were not added in these combinations. So, brinjal yields were comparatively lower than brinjal 100\% + mungbean $60 \%$ and brinjal $100 \%+$ blackgram $60 \%$ intercropping system.

\section{Companion crop yield}

On an average, the yield of red amaranth, leaf amaranth, jute, mungbean and blackgram under intercrops were $7.52,8.39,7.05,1.13$ and $0.99 \mathrm{t} / \mathrm{ha}$, respectively (Table 2). Results showed that, among the leafy vegetables, leaf amaranth showed higher yield $(8.39 \mathrm{t} / \mathrm{ha})$ in intercropping followed by red amaranth $(7.52$ t/ha) and jute as vegetable (7.05 t/ha). Similarly, between the legumes crops mungbean yield (1.13 t/ha) and blackgram (0.99 t/ha) was almost similar.

Table 2. Yield of companion crops and Brinjal equivalent yield (BEY) under brinjal-leafy vegetables-legumes intercropping system (pooled data of 2010 and 2011).

\begin{tabular}{c|c|c|c|c}
\hline Treatments & $\begin{array}{c}\text { Yield of leafy } \\
\text { vegetables/legumes } \\
\text { (t/ha) }\end{array}$ & BEY (t/ha) & $\begin{array}{c}\text { \% increase of } \\
\text { BEY over sole } \\
\text { brinjal }\end{array}$ & LER \\
\hline $\mathrm{T}_{1}$ & 7.52 & 19.04 & 15.67 & 1.16 \\
$\mathrm{~T}_{2}$ & 8.39 & 17.91 & 8.80 & 1.09 \\
$\mathrm{~T}_{3}$ & 7.05 & 18.30 & 11.18 & 1.11 \\
$\mathrm{~T}_{4}$ & 1.13 & 20.85 & 26.67 & 1.27 \\
$\mathrm{~T}_{5}$ & 0.99 & 19.49 & 18.40 & 1.18 \\
$\mathrm{~T}_{6}$ & - & 16.46 & - & 1.00 \\
\hline
\end{tabular}

$\mathrm{T}_{1}=$ Brinjal $100 \%+$ Red amaranth $100 \%, \mathrm{~T}_{2}=$ Brinjal $100 \%+$ Leaf amaranth $100 \%, \mathrm{~T}_{3}=$ Brinjal $100 \%+$ Jute $100 \%, \mathrm{~T}_{4}=$ Brinjal $100 \%+$ Mungbean $60 \%, \mathrm{~T}_{5}=$ Brinjal $100 \%+$ Blackgram $60 \%$ and $\mathrm{T}_{6}=$ Sole crop of brinjal

\section{Brinjal equivalent yield (BEY)}

Brinjal equivalent yield was expressed in total productivity. Brinjal equivalent yields were higher in all the intercrops (17.91-20.85 t/ha) than the sole crop of brinjal (16.46 t/ha). The highest brinjal equivalent yield (20.85 t/ha) was recorded in brinjal $100 \%+$ mungbean $60 \%$ intercropped combination which was followed by brinjal $100 \%$ + blackgram $60 \%$ (19.49 t/ha), brinjal 100\% + red amaranth $100 \%$ (19.04 t/ha) and brinjal 100\% + jute 100\% (18.30 t/ha) (Table 2) and the total productivity also increase of $15.67,8.80,11.17,26.67$ and 18.40 percent 
over sole brinjal. The result revealed that brinjal $100 \%+$ mungbean $60 \%$ led to higher total productivity than sole crops. Ahmed et al. (2013) also reported 28 to $45 \%$ yield advantages in okra-vegetables intercropping system.

\section{Land equivalent ratio (LER)}

Highest land equivalent ratio (1.27) was recorded under brinjal $100 \%+$ mungbean $60 \%$ intercropping system followed by brinjal $100 \%$ + blackgram $60 \%$ (Table 2). The lowest LER (1.09) was in brinjal 100\% + leaf amaranth $100 \%$ intercropped combination. LER of different crop combinations ranged from 1.09 to 1.27 indicating $9-27 \%$ yield increase by intercropping. The mean values of LER (more than one) in all intercropping treatments revealed that land was more efficiently utilized under intercropping than under sole cropping of brinjal.

Table 3. Cost benefit analysis of brinjal-leafy vegetables-legumes intercropping system (pooled data of 2010 and 2011).

\begin{tabular}{c|c|c|c|c}
\hline Treatments & Gross return (Tk/ha) & $\begin{array}{c}\text { Total cost } \\
(\mathrm{Tk} / \mathrm{ha})\end{array}$ & $\begin{array}{c}\text { Gross margin } \\
(\mathrm{Tk} / \mathrm{ha})\end{array}$ & BCR \\
\hline $\mathrm{T}_{1}$ & 285610 & 96257 & 189353 & 2.97 \\
$\mathrm{~T}_{2}$ & 268600 & 96557 & 172043 & 2.78 \\
$\mathrm{~T}_{3}$ & 274500 & 97157 & 177343 & 2.83 \\
$\mathrm{~T}_{4}$ & 312750 & 100057 & 212693 & 3.13 \\
$\mathrm{~T}_{5}$ & 292350 & 97577 & 194773 & 3.00 \\
$\mathrm{~T}_{6}$ & 246900 & 91057 & 155843 & 2.71 \\
\hline
\end{tabular}

Price: Brinjal: Tk 15/kg, Red amaranth: Tk $8 / \mathrm{kg}$, Leaf amaranth: Tk $5 / \mathrm{kg}$, Jute (as patshak): Tk 7/kg, Mungbean: Tk 60/kg, Blackgram: Tk 50/kg

\section{Cost benefit analysis}

Intercropping combination of brinjal with leafy vegetables and legumes showed higher monetary return than sole crop (Table 3). The highest gross return (Tk.312750/ha) was recorded from brinjal 100\% + mungbean 60\% intercrop combination which was 21.06 percent higher than sole brinjal (Table 3). This intercropping combination also gave the higher gross margin (Tk 212693/ha) and benefit cost ratio (3.13) followed by brinjal $100 \%$ + blackgram $60 \%$ with BCR (3.00). Among the intercrops, the lowest gross return (Tk 268600/ha), gross margin (Tk 172043/ha) and BCR (2.78) were obtained from the combination of brinjal $100 \%$ + leaf amaranth $100 \%$ followed by jute as intercrop. The results of increased productivity and returns were consistent with the earlier reports of yield advantage of crop mixture compared to monoculture (Akhteruzzaman and Quayyum, 1991; Islam et al., 2012; Ahmed et al., 2013). 
Table 4. Monthly total rainfalls ( $\mathrm{mm})$ occurred during the growth period.

\begin{tabular}{|c|c|c|c|c|c|c|c|c|c|c|}
\hline \multirow[t]{2}{*}{ Month } & \multicolumn{2}{|l|}{ Brinjal } & \multicolumn{2}{|c|}{ RA/LA } & \multicolumn{2}{|c|}{ Jute } & \multicolumn{2}{|c|}{ Mungbean } & \multicolumn{2}{|c|}{ Blackgram } \\
\hline & 2010 & 2011 & 2010 & 2011 & 2010 & 2011 & 2010 & 2011 & 2010 & 2011 \\
\hline March & $\begin{array}{l}0.20 \\
(1)^{*}\end{array}$ & $\begin{array}{l}12.09 \\
(3)^{*}\end{array}$ & $\begin{array}{l}0.20 \\
(1)^{*}\end{array}$ & $\begin{array}{l}2.09 \\
2)^{*}\end{array}$ & $\begin{array}{l}0.20 \\
(1)^{*}\end{array}$ & $\begin{array}{c}12.09 \\
(2)^{*}\end{array}$ & $\begin{array}{l}0.20 \\
(1)^{*}\end{array}$ & $\begin{array}{l}12.09 \\
(2)^{*}\end{array}$ & $\begin{array}{l}0.20 \\
(1)^{*}\end{array}$ & $\begin{array}{c}12.09 \\
(2)^{*}\end{array}$ \\
\hline April & $\begin{array}{c}30.22 \\
(3)\end{array}$ & $\begin{array}{l}58.53 \\
(5)\end{array}$ & $\begin{array}{c}6.36 \\
(1)\end{array}$ & $\begin{array}{l}i 8.53 \\
(5)\end{array}$ & $\begin{array}{c}30.22 \\
(3)\end{array}$ & $\begin{array}{c}58.53 \\
(5)\end{array}$ & $\begin{array}{c}30.22 \\
(3)\end{array}$ & $\begin{array}{c}58.53 \\
(5)\end{array}$ & $\begin{array}{c}30.22 \\
(3)\end{array}$ & $\begin{array}{c}58.53 \\
(5)\end{array}$ \\
\hline May & $\begin{array}{c}135.24 \\
(8)\end{array}$ & $\begin{array}{c}164.81 \\
(8)\end{array}$ & - & - & - & - & $\begin{array}{c}117.74 \\
(7)\end{array}$ & $\begin{array}{c}164.81 \\
(8)\end{array}$ & $\begin{array}{c}93.87 \\
(5)\end{array}$ & $\begin{array}{c}164.81 \\
(8)\end{array}$ \\
\hline June & $\begin{array}{c}115.88 \\
(8)\end{array}$ & $\begin{array}{c}202.05 \\
(9)\end{array}$ & - & - & - & - & - & - & - & - \\
\hline July & $\begin{array}{c}83.84 \\
(6)\end{array}$ & $\begin{array}{c}227.48 \\
(10)\end{array}$ & - & - & - & - & - & - & - & - \\
\hline August & $\begin{array}{l}61.09 \\
(5)\end{array}$ & $\begin{array}{c}451.81 \\
(12)\end{array}$ & - & - & - & - & - & - & - & - \\
\hline September & $\begin{array}{l}91.35 \\
(8)\end{array}$ & $\begin{array}{c}245.64 \\
(10)\end{array}$ & - & - & - & - & - & - & - & - \\
\hline October & $\begin{array}{c}69.21 \\
(4)\end{array}$ & 0.0 & - & - & - & - & - & - & - & - \\
\hline November & 0.0 & 0.0 & - & - & - & - & - & - & - & - \\
\hline Total & $\begin{array}{c}587.03 \\
(43)\end{array}$ & $\begin{array}{c}1362.41 \\
(57)\end{array}$ & $\begin{array}{l}6.56 \\
(2)\end{array}$ & $\begin{array}{c}70.62 \\
(7)\end{array}$ & $\begin{array}{c}30.42 \\
(4)\end{array}$ & $\begin{array}{c}70.67 \\
(7)\end{array}$ & $\begin{array}{c}148.16 \\
(11)\end{array}$ & $\begin{array}{c}235.43 \\
(15)\end{array}$ & $\begin{array}{c}124.29 \\
(9)\end{array}$ & $\begin{array}{c}235.43 \\
(15)\end{array}$ \\
\hline Average & 974.7 & $2(50)$ & 38.5 & $59(5)$ & 50.5 & $4(6)$ & 191.79 & $9(13)$ & 179.8 & $6(12)$ \\
\hline
\end{tabular}

Source: Bangladesh Sugarcane Research Institute (BSRI), Ishurdi, Pabna

$\mathrm{RA}=$ Red amaranth, LA= Leaf amaranth, *The figures in the parentheses indicate the number of rainy days.

\section{Conclusion}

The results revealed that all intercropping treatments were suitable as compared to sole treatments but brinjal $100 \%+$ mungbean $60 \%$ intercropped combination i.e., brinjal spacing $(100 \mathrm{~cm} \times 75 \mathrm{~cm})$ and three rows of mungbean, $30 \mathrm{~cm}$ apart with continuous seeding was more productive and profitable in respect of brinjal equivalent yield and monetary return. Besides, mungbean biomass could help in soil fertility point of view.

\section{References}

Ahmad, R., A. Jabbar, A. H. Ahmad, E. Ullah and I. H. Bhatti. 2007. Evaluation of direct seeded upland rice-based intercropping system under strip planting geometry. Pakistan J. Agric. Sci. 44:1-5 
Ahmed F., M. N. Islam, M. S. Alom, M. A. I. Sarker, and M. A. Mannaf. 2013. Study on itercropping leafy vegetables with okra (Abelmoschus esculentus 1.). Bangladesh J. Agril. Res. 38(1): 137-143

Akhteruzzaman, M. and M. A. Quayyum.1991. Intercropping of maize with three varieties of groundnut at two levels of plant population. Bangladesh J. Agril. Sci. 18(1):39-44.

Bhatti, I. H. 2005. Agro-physiological studies on sesame-legume intercropping system in different geometric arrangements. Ph. D. Thesis, Department of Agronomy University of Agriculture Faisalabad, Pakistan

Islam M. R., M. A. K. Mian and M. T. Rahman. 2012. Suitability of intercropping sesame with mukhikachu. Bangladesh J. Agril. Res. 37(4): 625-634.

Malik, M. A., M. F. Saleem, M. sana and A. Aziz. 2002. Agro economic expression of different relay crops after rice harvest under conventional and zero tillage. Int. J. Agric. Biol., 4: 277-278

Mian, M. A. K. 2008. Performance of maize oriented cropping patterns under different nutrient management. Ph. D. Dissertation. Dept. Agron. Bangladesh Agril. Univ., Mymensingh. Pp. 31-137.

MOA (Ministry of Agriculture). 2014. Hand Book of Agricultural Statistics, December 2007. Government of the Peoples Republic of Bangladesh. http://www.moa.gov.bd/ statistics/ statistics.htm

Nazir, M. S., A. Jabbar, I. Ahmad, S. Nawaz and I. H. Bhatti. 2002. Production potential and economics of intercropping in autumn-planted sugarcane. Int. J. Agric. Biol. 4:140-142 